\title{
Immobilization Screening and Characterization of an Alcohol Dehydrogenase and its Application to the Multi-Enzymatic Selective Oxidation of 1,-Omega-Diols
}

\section{OPEN ACCESS \\ Edited by:}

Amanda Silva de Miranda, Federal University of Minas Gerais,

Brazil

Reviewed by:

Sanjay Kumar Singh Patel, Konkuk University, South Korea

Yunting Liu,

Hebei University of Technology, China

*Correspondence:

Fernando López-Gallego

flopez@cicbiomagune.es

tORCID:

Javier Santiago-Arcos, orcid.org/0000-0001-6461-689X

Susana Velasco-Lozano, orcid.org/0000-0001-9478-6750

Aitiziber L. Cortajarena, orcid.org/0000-0002-5331-114X

Specialty section: This article was submitted to Biocatalysis,

a section of the journal

Frontiers in Catalysis

Received: 26 May 2021 Accepted: 30 June 2021 Published: 19 July 2021

Citation:

Santiago-Arcos J, Velasco-Lozano S,

Diamanti E, Cortajarena AL and López-Gallego F (2021) Immobilization Screening and Characterization of an Alcohol Dehydrogenase and its

Application to the Multi-Enzymatic Selective Oxidation of 1,-Omega-Diols.

Front. Catal. 1:715075.

doi: 10.3389/fctls.2021.715075

\begin{abstract}
Javier Santiago-Arcos ${ }^{1 \dagger}$, Susana Velasco-Lozano ${ }^{1 \dagger}$, Eleftheria Diamanti ${ }^{1}$, Aitziber L. Cortajarena ${ }^{1,2+}$ and Fernando López-Gallego ${ }^{1,2 *}$
\end{abstract}

${ }^{1}$ Center for Cooperative Research in Biomaterials (CICbiomaGUNE) - Basque Research and Technology Alliance (BRTA), Donostia-San Sebastián, Spain, ${ }^{2} I K E R B A S Q U E$, Basque Foundation for Science, Bilbao, Spain

Alcohol dehydrogenase from Bacillus (Geobacillus) stearothermophilus (BsADH) is a NADHdependent enzyme catalyzing the oxidation of alcohols, however its thermal and operational stabilities are too low for its long-term use under non-physiological conditions. Enzyme immobilizations emerges as an attractive tool to enhance the stability of this enzyme. In this work, we have screened a battery of porous carriers and immobilization chemistries to enhance the robustness of a His-tagged variant of BsADH. The selected carriers recovered close to $50 \%$ of the immobilized activity and increased enzyme stability from 3 to 9 times compared to the free enzyme. We found a trade-off between the half-life time and the specific activity as a function of the relative anisotropy values of the immobilized enzymes, suggesting that both properties are oppositely related to the enzyme mobility (rotational tumbling). The most thermally stable heterogeneous biocatalysts were coupled with a NADH oxidase/catalase pair co-immobilized on porous agarose beads to perform the batch oxidation of five different $1, \omega$-diols with in situ recycling of $\mathrm{NAD}^{+}$. Only when His-tagged BsADH was immobilized on porous glass functionalized with $\mathrm{Fe}^{3+}$, the heterogeneous biocatalyst oxidized 1, 5-pentanediol with a conversion higher than $50 \%$ after five batch cycles. This immobilized multi-enzyme system presented promising enzymatic productivities towards the oxidation of three different diols. Hence, this strategical study accompanied by a functional and structural characterization of the resulting immobilized enzymes, allowed us selecting an optimal heterogeneous biocatalyst and their integration into a fully heterogeneous multi-enzyme system.

Keywords: protein immobilization, biocatalysis, biooxidation, porous materials catalysis, his-tag

\section{INTRODUCTION}

Oxidation reactions have been employed as one of the most useful reactions in chemical manufacturing to produce aldehydes as building blocks for the synthesis of more complex molecules such as carboxylic acids and aminoalcohols (Velasco-Lozano et al., 2020; Wu et al., 2021). However, the most of the chemical procedures present disadvantages such as poor selectivity and low sustainability (Wu et al., 2021). Selectivity is mandatory when the regioselective oxidation of only one primary hydroxyl group of the $1, \omega$-diols needs to be oxidized to its corresponding 
$\omega$-hydroxy aldehydes. These hydroxy aldehydes are excellent building blocks for the manufacturing of more valuable substrates, for instance, $\omega$-hydroxy acids ( $\omega$-HA), which are used in the industrial production of polyesters, resins, plasticizers, and lubricants (Kornhauser et al., 2010; Köckritz and Martin, 2011; Chung et al., 2015). Several different chemical approaches (i.e., organometallics) are well known to carry out the oxidation of primary alcohols, but they lack the demanded selectivity and generate undesired overoxidized products. (Tojo and Fernandez, 2006).

As alternative, biocatalysis can provide the suitable selectivity to these chemical transformations. The biocatalyst driven oxidations allow performing the reactions under mild conditions and more importantly avoid the use of tedious protection groups due to the exquisite enzyme selectivity (Puetz et al., 2020). In particular, alcohol dehydrogenases (ADHs; EC 1.1.1.1) are widely used for the oxidation of alcohols in combination with redox nicotinamide cofactors $\left(\operatorname{NAD}(\mathrm{P})^{+}\right)$as hydride acceptors (Kara et al., 2013). Within this enzyme family, $\mathrm{ADH}$ from Bacillus (Geobacillus) stearothermophilus (BsADH) have been successfully exploited for the selective and versatile oxidation of $1, \omega$-diols (Kirmair et al., 2015). In fact, this enzyme has been coupled to transaminases to sequentially transform $1, \omega$-diols into aminoalcohols (Schrittwieser et al., 2011; Velasco-Lozano et al., 2020). BsADH catalyzes the hydride transfer from one hydroxyl group of the substrate to $\mathrm{NAD}^{+}$through a compulsory ordered mechanism similar to other alcohol dehydrogenases (Dickinson and Monger, 1973). For this reason, BsADH requires an in situ recycling of $\mathrm{NAD}^{+}$when exploited in applied biocatalysis. Several enzymatic and chemoenzymatic recycling systems have been proposed for this type of biotransformations using laccases (Pham et al., 2015) and NADH oxidases (Nowak et al., 2015) among others.

One of the major limitations of using isolated ADHs at the industrial level is their low stability under process operation conditions. Therefore, the industrial application of free dehydrogenases faces several drawbacks in terms of operational stability and long-term use (Basso and Serban, 2019). To solve these problems, enzyme immobilization allows the generation of robust heterogeneous biocatalysts that are easily separated from the reaction products, can increase the enzyme volumetric activity (high protein loads), can be readily recycled for several consecutive batch cycles and are easily integrated in flow reactors for continuous production of the target product (Sheldon et al., 2021). When the immobilization protocol is well designed both catalytic efficiency and stability can be enhanced (Garcia-Galan et al., 2011). The selection of the carrier material is crucial to achieve highly robust and efficient heterogeneous biocatalysts (Cantone et al., 2013). Currently new immobilization trends based on selfassembled inorganic chassis have also proven their usefulness as protein carriers (Liu et al., 2021; Zhang et al., 2021). Besides the carrier properties, the enzyme orientation upon binding must also be considered when designing an immobilization protocol that pursues maximizing the performance of the resulting heterogenous biocatalysts (Mateo et al., 2007a). Enzymes can be immobilized on carriers through several strategies such as physical absorption, hydrophobic interaction and electrostatic forces (Liu et al., 2017). However, these strategies fail to control the orientation of the enzyme in the carrier. Hence, oriented immobilization is gaining momentum in applied biocatalysis as endorses the most recent process developments, involving dehydrogenases. Immobilization of His-tagged enzymes is one of the most preferred strategies to control the enzyme orientation due to its versatility to purify and immobilize recombinantly expressed enzymes on a great variety of carries and in one-pot (Mateo et al., 2006; Patel et al., 2017). Paradisi's and Flitch's groups (Contente et al., 2019; Marchesi et al., 2020) are exploiting His-tagged enzymes to control their orientation upon immobilization on porous carriers functionalized with metal-complexes. These immobilized systems enable to carry out telescoped synthetic schemes in flow. One of the limitations of His-tag driven immobilization is the reversibility of the attachment between the enzyme and the carriers. Such issue may be overcome by using heterofunctional carriers that, besides the metal-complex, are also functionalized with either aldehydes or epoxides that ultimately establish irreversible bonds with the site-directed immobilized enzymes (Bolivar et al., 2006; Mateo et al., 2007a). In particular, cobalt-chelates and epoxides have been exploited to fabricate highly robust biocatalysts that have been applied for large-scale biotransformations and flow-biocatalysis (Contente et al., 2019; Padrosa et al., 2020). As alternative to carriers functionalized with cobalt-chelates, a new generation of commercially available carriers based on porous glass functionalized with $\mathrm{Fe}^{3+}$-catechol are gaining momentum in applied biocatalysis (Thompson et al., 2019). Although a wide range of enzymes have been successfully immobilized on solid carriers to enhance their functional properties, structural characterizations of the immobilized enzymes are also demanded to understand the structural changes occurred upon the immobilization and further optimize the fabrication of heterogeneous biocatalysts.

In this work, we present an immobilization screening for Histagged BsADH (His-BsADH) aiming at maximizing the activity and the stability of the resulting heterogeneous biocatalysts for their further integration in one-pot multi-enzyme systems to selectively oxidize $1, \omega$-diols to yield $\omega$-hydroxy aldehydes. In previous attempts, the immobilization of BsADH resulted in an active heterogeneous biocatalyst that could be reused (VelascoLozano et al., 2020), nevertheless, the clues underlying the enzymatic stabilization still remain to be elucidated. We have performed an extensive characterization of the immobilized enzymes on the different porous carriers, analyzing their immobilization parameters, thermal stability, spatial distribution, and the structural changes that enzymes undergo on the surface of each carrier. The optimal heterogeneous biocatalyst selected among the different porous carriers tested herein, was then applied for the selective oxidation of five different diols in combination with the best enzyme partner for the in situ recycling of $\mathrm{NAD}^{+}$ (Rocha-Martin et al., 2015) selected from two different NADH oxidases. 


\section{MATERIALS AND METHODS}

\section{Materials}

Substrates as 1,4-butanediol (1s), 1,5-propanediol (2s), 1,6hexanediol (3s), diethylene glycol (4s), 3-methyl-1,5pentanediol (5s), 5-hydroxypentanal (2p), 2Hydroxytetrahydropyran (lactol), $\delta$-valerolactone, the enzyme catalase from bovine liver, kanamycin sulfate from Streptomyces kanamyceticus, ampicillin, flavin-adeninedinucleotide sodium salt $\left(\mathrm{FAD}^{+}\right)$, fluorescein isothiocyanate (FITC), rhodamine $\mathrm{B}$ isothiocyanate, acetic anhydride and n-methylimidazole were purchased from Sigma-Aldrich (St. Lous, IL, United States). Isopropyl $\beta$-D-thiogalactopyranoside (IPTG), nicotinamide adenine dinucleotide sodium salt $\left(\mathrm{NAD}^{+}\right)$ and $\beta$-nicotinamide adenine dinucleotide reduced (NADH) were purchased from GERBU Biotechnik GmbH (Wieblingen, Germany). Low density (LdAG-Co ${ }^{2+} ; 15 \mu \mathrm{mol}$ of $\mathrm{Co}^{2+} \mathrm{x} \mathrm{g}$ carrier $^{-1}$ ) and high density (HdAG-Co ${ }^{2+} ; 30 \mu \mathrm{mol}$ of $\mathrm{Co}^{2+} \mathrm{x} \mathrm{g}$ carrier $^{-1}$ ) cobalt-activated agarose microbeads 4BCL (particle size; $50-150 \mu \mathrm{m})$ were purchased from ABT technologies (Madrid, Spain). TALON metal affinity resin (tAG-Co ${ }^{2+}$ ) (particle size $45-165 \mu \mathrm{m} ; 20 \mu \mathrm{mol}$ of $\mathrm{Co}^{2+} \mathrm{x} \mathrm{g}_{\text {carrier }}{ }^{-1}$ ) was purchased from Takara Bio Group (Göteborg,Sweden). Metal-ion affinity enzyme immobilization EziG (1, 2 and 3; particle size $75-150 \mu \mathrm{m} ; 10 \mu \mathrm{mol} \mathrm{Fe}^{3+} \mathrm{x} \mathrm{g}^{-1}$ were kindly donated by EnginZyme (Solna, Sweden). 6BCL glyoxyl-agarose beads were prepared as described elsewhere (Guisán, 1988). Precision plus protein TM standards, micro Bio-spinTM chromatographic columns and Bradford reagent were acquired from BIORAD. All other reagents and solvents were of analytical grade or superior.

\section{Bacterial Strains and Growth Conditions}

His-BsADH (López-Gallego and Yate, 2015), LpNOX (Nowak et al., 2015) and TtNOX (Rocha-Martin et al., 2011) were cloned and overexpressed in competent Escherichia coli BL21 cells transformed with the respective plasmids. Briefly, $1 \mathrm{~mL}$ of an overnight culture of E. coli BL21 (DE3) harboring each plasmid was used to inoculate $50 \mathrm{~mL}$ of Luria-Bertain (LB) medium containing kanamycin for His-BsADH and LpNOX (final concentration $30 \mu \mathrm{g} \times \mathrm{mL}^{-1}$ ) and ampicillin for TtNOX (final concentration $60 \mu \mathrm{g} \times \mathrm{mL}^{-1}$ ). The resulting culture was aerobically incubated at $37^{\circ} \mathrm{C}$ with orbital shaking at $250 \mathrm{rpm}$ until the OD $600 \mathrm{~nm}$ reached 0.6. Afterwards, the culture was induced with $1 \mathrm{mM}$ IPTG. His-BsADH and TtNOX were induced for $3 \mathrm{~h}$ at $37^{\circ} \mathrm{C}$, while LpNOX was induced for $16 \mathrm{~h}$ at $21^{\circ} \mathrm{C}$. After the induction time, cells were harvested by centrifugation at $1,157 \mathrm{~g}$ for $30 \mathrm{~min}$ at $4^{\circ} \mathrm{C}$. Supernatants were discarded and the pellet was resuspended in $5 \mathrm{~mL}$ of a solution of $50 \mathrm{mM} \mathrm{NaCl}, 10 \mathrm{mM}$ imidazole in $25 \mathrm{mM}$ sodium phosphate buffer solution at $\mathrm{pH}$ 7. Cells were lysed by sonication using an Ultrasonic sonicator LABSONIC P, at $50 \%$ amplitude ( $0.5 \mathrm{~s} \mathrm{ON/}$ $0.5 \mathrm{~s}$ OFF) for $15 \mathrm{~min}$ in an ice-water bath. The suspension was then centrifuged at $12,298 \mathrm{~g}$ for $30 \mathrm{~min}$ at $4^{\circ} \mathrm{C}$ and the supernatant containing the cell extract with the His-tagged protein was collected and employed for further purification and/or immobilization.

\section{Purification and Immobilization of His-BsADH on the Different Carriers}

10 volumes of crude cell extract containing the His-BsADH were mixed with 1 volume of carrier and incubated under orbital shaking for $1 \mathrm{~h}$ at $4^{\circ} \mathrm{C}$. Later, the suspension was filtered and the microbeads containing the enzyme were washed with 5 volumes of $25 \mathrm{mM}$ phosphate buffer at $\mathrm{pH} 7$. Resulting resins were stored at $4^{\circ} \mathrm{C}$ until their usage. Additionally, 10 volumes of crude cell extract containing the His-BsADH were mixed with 1 volume of LdAG-Co ${ }^{2+}$ microbeads and incubated under orbital shaking for $1 \mathrm{~h}$ at $4^{\circ} \mathrm{C}$. Later, the suspension was filtered and the microbeads containing the enzyme were washed with 5 volumes of $25 \mathrm{mM}$ phosphate buffer at $\mathrm{pH}$ 7. Sequentially, His-BsADH was eluted by the addition of 10 volumes of $300 \mathrm{mM}$ imidazole in $25 \mathrm{mM}$ phosphate buffer at $\mathrm{pH} 7$ for $1 \mathrm{~h}$ at $4^{\circ} \mathrm{C}$ under orbital shaking. Lastly, SDS-PAGE and Bradford protein assay (Bradford, 1976) were carried out after each production batch to determine the purity, the concentration, the bound enzyme to the carriers and the specific activity of the enzyme.

\section{Immobilization of the Co-Factor Regeneration System TtNOX/BICAT on Glyoxyl and LpNOX in LdAG-Co ${ }^{2+}$}

One volume of glyoxyl-6BCL carrier equilibrated with $100 \mathrm{mM}$ sodium bicarbonate buffer at $\mathrm{pH} 10$ was incubated with 10 volumes of enzymatic solution containing $0.26 \mathrm{mg} \mathrm{x} \mathrm{mL}^{-1}$ of purified TtNOX and $10 \mathrm{mg} \times \mathrm{mL}^{-1}$ of BlCAT in $100 \mathrm{mM}$ sodium bicarbonate buffer at $\mathrm{pH} 10$ and incubated for $3-4 \mathrm{~h}$ at $4^{\circ} \mathrm{C}$. Afterwards, the supernatant was discarded, and the carrier was incubated with 10 volumes of a solution containing $1 \mathrm{mg} \times \mathrm{mL}^{-1}$ of sodium borohydride in $100 \mathrm{mM}$ sodium bicarbonate buffer at $\mathrm{pH}$ 10 for $30 \mathrm{~min}$. Finally, the suspension was filtered and washed with 5 volumes of $25 \mathrm{mM}$ sodium phosphate buffer at $\mathrm{pH} 7.10$ volumes of crude cell extract containing the His-tagged LpNOX were mixed with 1 volume of $\mathrm{LdAG}-\mathrm{Co}^{2+}$ microbeads and incubated under orbital shaking for $1 \mathrm{~h}$ at $4^{\circ} \mathrm{C}$. Later, the suspension was filtered and the microbeads containing the enzyme were washed with 5 volumes of $25 \mathrm{mM}$ phosphate buffer at $\mathrm{pH} 7$.

\section{Calculation of Immobilization Parameters}

For any immobilization protocol herein performed, we calculated the following immobilization parameters:

Load is defined as the mass of immobilized protein per gram of carrier. It is calculated as follows:

Load $\left(\mathrm{mgx} g^{-1}=\left(\right.\right.$ Offered protein $\left(\mathrm{mg} \mathrm{x} \mathrm{mL}^{-1}\right)$

- protein in supernantant $\left(\mathrm{mg} \mathrm{x} \mathrm{mL}^{-1}\right) \times\left(\frac{\text { immobilization volume }(m L)}{\text { carrier mass }(g)}\right)$

Immobilization yield $(\psi)$ is defined as the percentage of the offered enzyme that is immobilized on the carrier. It is calculated as follows:

$$
\psi=\left(\frac{\text { Offered activity }- \text { supernantant activity }}{\text { Offered activity }}\right) \times 100
$$


Immobilized activity (iA) is defined as the theoretical activity bound to the carrier. It is calculated as follows:

$$
\text { iA }\left(U x g^{-1}\right)=\left(\text { Offered acivity) } x\left(\frac{\psi}{100}\right)\right.
$$

Recovered activity $\left(\mathrm{RA} / \mathrm{U} \times \mathrm{g}^{-1}\right)$ is defined as the real enzyme activity per mass of carrier measured through the corresponding colorimetric assay upon the immobilization.

Relative recovered activity is defined as the percentage of the theoretically immobilized activity (iA) exhibited by the enzyme upon the immobilization protocol. It is calculated as follows:

$$
\operatorname{rRA}(\%)=\left(\frac{R A}{i A}\right) \times 100
$$

Immobilized specific activity (iSA) is defined as the activity per mass of the immobilized enzyme. It is calculated as follows:

$$
\text { iSA }\left(\mathrm{U} \times m g^{-1}\right)=\left(\frac{R A}{\text { Load }}\right)
$$

\section{Enzymatic Activity Measurement of Both Free and Immobilized Enzymes}

Enzyme activity of the different systems was spectrophotometrically measured in UV flat bottom and transparent 96-well microplates, employing a Microplate Reader Epoch 2, BioTek ${ }^{\circledR}$. Data processing was done with Gen5 software.

\section{ADH Activity Assay}

$200 \mu \mathrm{L}$ of a reaction mixture containing $10 \mathrm{mM}$ 1,5-pentanediol, $1 \mathrm{mM} \mathrm{NAD}^{+}$, in $50 \mathrm{mM}$ Tris-HCl buffer at $\mathrm{pH} 8$ were incubated with either $5 \mu \mathrm{L}$ of free enzyme or $10 \mu \mathrm{L}$ suspension $1: 10$ of the different immobilized biocatalysts at $30^{\circ} \mathrm{C}$. The increase in absorbance was monitored at $340 \mathrm{~nm}$. One unit of activity was defined as the amount of enzyme that was required to reduce $1 \mu \mathrm{mol}$ of $\mathrm{NAD}^{+}$per minute at the assayed conditions.

\section{NOX Activity Assay}

$200 \mu \mathrm{L}$ of a reaction mixture containing $0.2 \mathrm{mM} \mathrm{NADH}$, $0.15 \mathrm{mM} \mathrm{FAD}^{+}$in $50 \mathrm{mM}$ Tris- $\mathrm{HCl}$ buffer at $\mathrm{pH} 8$ were incubated with either $5 \mu \mathrm{L}$ of free enzyme or $10 \mu \mathrm{L}$ suspension 1:10 of the different immobilized biocatalysts at $30^{\circ} \mathrm{C}$. The decrease in absorbance was monitored at $340 \mathrm{~nm}$. One unit of activity was defined as the amount of enzyme that was required to oxidize $1 \mu \mathrm{mol}$ of $\mathrm{NADH}$ per minute at the assayed conditions.

\section{Catalase Activity Assay}

$200 \mu \mathrm{L}$ of a reaction mixture containing $35 \mathrm{mM} \mathrm{H}_{2} \mathrm{O}_{2}$, in $50 \mathrm{mM}$ Tris- $\mathrm{HCl}$ buffer at $\mathrm{pH} 8$ were incubated with either $5 \mu \mathrm{L}$ of free enzyme or $10 \mu \mathrm{L}$ suspension 1:10 of different immobilized biocatalysts at $30^{\circ} \mathrm{C}$. The decrease in the absorbance at $240 \mathrm{~nm}$ was monitored. One unit of activity was defined as the amount of enzyme that was required to disproportionate $1 \mu \mathrm{mol}$ of $\mathrm{H}_{2} \mathrm{O}_{2}$ per minute at the assayed conditions.

\section{Protein Labeling with Fluorescent Probes}

Fluorescent labeling of the enzyme was done using a methodology reported elsewhere (Holmes and Lantz, 2001). Briefly, an enzyme solution of $0.25 \mathrm{mg} \times \mathrm{mL}^{-1}$ in $100 \mathrm{mM}$ of sodium bicarbonate buffer at $\mathrm{pH} 8.5$ was mixed with FITC or rhodamine $\mathrm{B}$ solution at 1:10 molar ratio (FITC and rhodamine $\mathrm{B}$ stocks were prepared in DMSO at $10 \mathrm{mg} \times \mathrm{mL}^{-1}$ ). The labelling reaction was then incubated for $1 \mathrm{~h}$ under gentle shaking at $25^{\circ} \mathrm{C}$. Later, unreacted FITC or rhodamine B was eliminated by either filtering the enzyme solution through a tangential ultrafiltration unit $(10 \mathrm{kDa})$ or dialyzing the enzyme solution with a $25 \mathrm{mM}$ sodium phosphate buffered solution at $\mathrm{pH} 7$ until no coloration was observed in the filtered solution.

\section{Confocal Laser Scanning Microscopy (CLSM) Imaging}

The localization and distribution of fluorophore-labelled HisBsADH immobilized along the different carriers were visualized with a confocal microscope Spectral ZEISS LSM 880 microscope equipped with an excitation laser, $\lambda_{\mathrm{ex}}=561 \mathrm{~nm}$ for Rhodamine $\mathrm{B}$ and emission filter.

Confocal imaging was done using a $\times 20$ and $\times 40$ water objectives and a 1:200 (w:v) buffered suspension in $25 \mathrm{mM}$ phosphate buffer at $\mathrm{pH} 7$, of each biocatalyst with the fluorescently labeled immobilized enzymes. The resulting micrographs were analyzed with FIJI (Schindelin et al., 2012). From confocal images, we obtained an average and normalized fluorescence radius profile, using FIJI software and its plugin module for radial profile generation (developed by Paul Baggethun). Subsequently, a Gaussian fit was applied to the obtained profiles of 10 single beads of similar size. Then, we searched for the fitted data point that corresponds to the $50 \%$ of the maximum normalized fluorescence fitted peak ( $\mathrm{y}_{\mathrm{FWHM}}$ ), and the corresponding radius coordinate $\left(\mathrm{x}_{\mathrm{FWHM}}\right)$ to that data point was then subtracted from the radius $(\mathrm{R})$ of the analyzed bead to finally obtain the FWHM (full width half maximum) that means the infiltration distance of the enzyme into the bead surface.

\section{Thermal Inactivation}

Inactivation of both soluble and immobilized biocatalysts were carried out by incubating them in $25 \mathrm{mM}$ sodium phosphate at $\mathrm{pH} 7$ at $25-90^{\circ} \mathrm{C}$ for $1 \mathrm{~h}$. The residual activity upon the thermal incubation was quantified and the $\mathrm{T}_{50}$ was calculated as the temperature where the enzyme exhibits the $50 \%$ of its initial activity (prior to the thermal incubation). For the kinetic thermal inactivation, both free and immobilized enzymes were incubated in a suspension 1:10 (w:v) with $25 \mathrm{mM}$ sodium phosphate at $\mathrm{pH} 7$ at $70^{\circ} \mathrm{C}$. Samples were withdrawn at different times and their residual activities were measured by the $\mathrm{ADH}$ activity assay. The activity of the different time points was normalized with the enzyme activity at time zero as reference. In order to calculate the half-life times, the obtained experimental measurements were adjusted to a 3-parameters biexponential kinetic inactivation model (Aymard and Belarbi, 2000). 


\section{Analysis of Intrinsic Tryptophan Fluorescence}

Immobilized biocatalysts loading $0.5 \mathrm{mg}$ of protein $\times \mathrm{g}$ carrier $^{-1}$ were used for this experiment. The intrinsic fluorescence of free and immobilized His-BsADH was measured before and after the samples were incubated at $80^{\circ} \mathrm{C}$ for $1 \mathrm{~h}$. To that aim, $70 \mu \mathrm{g}$ of either free or immobilized enzymes were placed in a 96-well dark plate and the fluorescence emission spectra was recorded between 300 and $500 \mathrm{~nm}$ upon the sample excitation at $280 \mathrm{~nm}$, using emission band widths of $5 \mathrm{~nm}$. All spectroscopic measurements were performed in $25 \mathrm{mM}$ phosphate buffer at $\mathrm{pH} 7$.

\section{Anisotropy Measurements}

The polarized fluorescence of immobilized samples loaded with $0.5 \mathrm{mg}$ of FTIC-labelled His-BsADH was measured to determine the fluorescence anisotropy of FTIC conjugated to the free and immobilized proteins. In order to calculate the anisotropy values, $3 \mathrm{ng}$ of either free or immobilized enzyme were placed into a 96well dark plate and measured in a Microplate Reader Synergy H1, BioTek $^{\circledR}$. Anisotropy values were obtained according to Eq. $\mathbf{1}$.

$$
r=\frac{I_{z}-I_{y}}{I_{T}}
$$

where $I_{\mathrm{z}}$ represents the parallel fluorescence intensity, $I_{\mathrm{y}}$ represents the perpendicular fluorescence intensity and $I_{\mathrm{T}}$ represents the total fluorescence intensity that is calculated by:

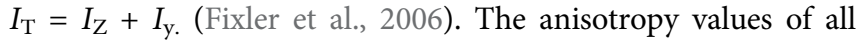
immobilized samples were normalized to the anisotropy of the free enzyme. Values higher than one mean enzymes with higher rotational tumbling than the free enzyme, while values lower than one mean enzyme with lower rotational tumbling than the free enzyme.

\section{Operational Stability of the Immobilized Biocatalysts}

$50 \mathrm{mg}$ of His-BsADH immobilized on LdAG-Co ${ }^{2+}, \mathrm{AG}^{-\mathrm{Co}^{2+}} / \mathrm{E}$ and EziG1 plus $125 \mathrm{mg}$ of TtNOX/BlCAT on glyoxyl were placed inside a $1.5 \mathrm{~mL}$ Bio-spinTM chromatographic column with $600 \mu \mathrm{L}$ of reaction mixture composed by $20 \mathrm{mM}$ of $2 \mathrm{~s}, 1 \mathrm{mM}$ of $\mathrm{NAD}^{+}, 0.15 \mathrm{mM}$ of $\mathrm{FAD}^{+}$in $50 \mathrm{mM}$ Tris- $\mathrm{HCl}$ at $\mathrm{pH} 8$. All reactions were performed at atmospheric pressure facilitating the oxygen diffusion to the reaction pot through an open syringe needle. After each reaction cycle $(24 \mathrm{~h})$, the reaction crudes were removed and collected for analysis, and the immobilized biocatalysts kept for the discontinuous use in the next batch cycle. Additionally, prior to continue with the next batch cycle, biocatalysts were washed with one volume of $25 \mathrm{mM}$ of phosphate buffer at $\mathrm{pH} 7$.

\section{Regioselective Reduction of Diols}

$25 \mathrm{mg}$ of His-BsADH immobilized on EziG1 plus $62.5 \mathrm{mg}$ of TtNOX/BlCAT on glyoxyl were placed inside a $1.5 \mathrm{~mL}$ BiospinTM chromatographic column with $800 \mu \mathrm{L}$ of reaction mixture composed by $20 \mathrm{mM}$ of substrate $(\mathbf{1}, \mathbf{2}, \mathbf{3}, \mathbf{4}$ or $\mathbf{5 s})$ $1 \mathrm{mM}$ of $\mathrm{NAD}^{+}, 0.15 \mathrm{mM}$ of FAD ${ }^{+}$in Tris- $\mathrm{HCl} 50 \mathrm{mM}$ at $\mathrm{pH} 8$.
All samples were erated through orbital shaking (250 r.p.m) at atmospheric pressure, facilitating the oxygen diffusion to the reaction pot through an open syringe needle. After $24 \mathrm{~h}$, all mixture reactions were removed and collected for analysis.

\section{Kinetic Analysis of the Cofactor Regeneration System}

$125 \mathrm{mg}$ of His-BsADH immobilized on EziG1 plus $312.5 \mathrm{mg}$ of TtNOX/BlCAT in glyoxyl and LpNOX-LdAG-Co ${ }^{2+}$ were placed inside a $5 \mathrm{~mL}$ Tube with $1.5 \mathrm{~mL}$ of reaction mixture consisted of $20 \mathrm{mM}$ of 1,5 -Pentanediol $1 \mathrm{mM}$ of $\mathrm{NAD}^{+}, 0.15 \mathrm{mM}$ of FAD ${ }^{+}$in Tris- $\mathrm{HCl} 50 \mathrm{mM}$ at $\mathrm{pH}$ 8. All samples were erated through orbital shaking (250 r.p.m) at atmospheric pressure, facilitating the oxygen diffusion to the reaction pot through an open syringe needle. To analyze the reaction course of each system, $200 \mu \mathrm{L}$ of the suspension were collected at different time points: $0.30,1,2,4$, 8 , and $24 \mathrm{~h}$. Suspensions were filtered through $1.5 \mathrm{~mL}$ BiospinTM chromatographic column to collect the reaction crudes collected for further chromatographic analysis.

\section{Gas Chromatography (GC)}

All reaction samples were derivatized as described elsewhere (Huang et al., 2020). Additionally, $50 \mu \mathrm{L}$ of aqueous reaction sample were placed in a $1.5 \mathrm{~mL}$ Eppendorf tube. Later, $150 \mu \mathrm{L}$ of ethyl acetate were added and vortexed for $20 \mathrm{~s} 20-50 \mathrm{mg}$ of anhydrous $\mathrm{MgSO}_{4}$ were added to dry samples before GC analysis using eicosane $2 \mathrm{mM}$ as external standard. Gas chromatography analyses were carried out in an Agilent 8,890 System gas chromatograph using a column of (5\%-phenyl)methylpolysiloxane (Agilent, J\&W HP-5 $30 \mathrm{~m} \times 0.32 \mathrm{~mm} \times$ $25 \mu \mathrm{m}$ ), helium as a carrier gas, and equipped with a flame ionization detector (FID). The temperature of the injector and FID detector were $280^{\circ} \mathrm{C}$ and $300^{\circ} \mathrm{C}$, respectively. Separation of compounds were done by the following temperature ramp: initial temperature $60^{\circ} \mathrm{C}$, maintained $2 \mathrm{~min}$, two ramps, first to $160^{\circ} \mathrm{C}$ at a rate of $10^{\circ} \mathrm{C} \times \mathrm{min}^{-1}$ and finally to $240^{\circ} \mathrm{C}$ at a rate of $20^{\circ} \mathrm{C} \times$ $\mathrm{min}^{-1}$. Retention times for substrates are: 1s: $4.17 \mathrm{~min}, 2 \mathrm{~s}$ : $5.78 \mathrm{~min}, \quad 3 \mathrm{~s}: \quad 7.46 \mathrm{~min}, \quad 4 s: 4.49 \mathrm{~min}, \quad$ 5s: $6.95 \mathrm{~min}, \quad 2-$ Hydroxytetrahydropyran (lactol): $3.38 \mathrm{~min}, \delta$-valerolactone: $6.01 \mathrm{~min}$, and eicosane (external standard): $16.60 \mathrm{~min}$.

\section{HPLC Analysis}

Before HPLC analysis samples were derivatized as described elsewhere (Hernandez et al., 2017). Briefly, $10 \mu \mathrm{L}$ of aqueous sample $(0.6-20 \mathrm{mM})$ were mixed with $50 \mu \mathrm{L}$ of O-benzylhydroxylamine hydrochloride $(130 \mathrm{mM}$ in pyridine/ methanol/water $33: 15: 2$ ) and incubated for $5 \mathrm{~min}$ at $25^{\circ} \mathrm{C}$. Afterwards, $500 \mu \mathrm{L}$ of methanol were added and then centrifuged $5 \mathrm{~min}$ at $13,450 \mathrm{~g}$. HPLC analysis was conducted in an Agilent 1,260 Infinity II chromatograph equipped with a Poroshell EC-C18 column $(4.6 \times 100 \mathrm{~mm}, 2.7 \mu \mathrm{m})$. Samples were detected at $215 \mathrm{~nm}$ and were eluted at $1 \mathrm{~mL} / \mathrm{min}$ flow rate employing two mobile phases, phase A composed by trifluoroacetic acid $0.1 \%$ in water, and phase B composed by trifluoroacetic acid $0.095 \%$ in $4: 1$ acetonitrile/water. Elution 
TABLE 1 | Immobilization parameters of His-BsADH on different porous carriers

\begin{tabular}{|c|c|c|c|c|c|c|c|c|c|c|}
\hline Material & Name & Functional group & $\begin{array}{c}\text { Group density } \\
\text { ( } \mu \mathrm{mol} / \mathrm{g})\end{array}$ & $\begin{array}{l}\text { Particle } \\
\text { size }(\mu \mathrm{m})\end{array}$ & $\begin{array}{l}\text { Load } \\
\text { (mg/g) }\end{array}$ & $\begin{array}{c}\Psi \\
(\%)\end{array}$ & iA $(U / g)$ & $R A(U / g)$ & rRA (\%) & iSA (U/mg) \\
\hline \multirow[t]{4}{*}{ Agarose } & LdAG-Co ${ }^{2+}$ & IDA-Co ${ }^{2+}$ & 15 & $50-150$ & 0.11 & $94 \pm 3$ & 0.94 & 0.44 & 47 & 4 \\
\hline & $\mathrm{HdAG}-\mathrm{Co}^{2+}$ & IDA-Co ${ }^{2+}$ & 30 & $50-150$ & 0.11 & $98 \pm 1$ & 0.97 & 0.45 & 47 & 4.1 \\
\hline & $\mathrm{AG}-\mathrm{Co}^{2+} / \mathrm{E}$ & IDA-Co ${ }^{2+} /$ Epoxide & 20 & $50-150$ & 0.11 & $99 \pm 4$ & 0.98 & 0.22 & 22 & 2 \\
\hline & tAG-Co ${ }^{2+}$ & $\mathrm{NTA}-\mathrm{Co}^{2+}$ & 20 & $45-165$ & 0.11 & $96 \pm 4$ & 0.95 & 0.46 & 49 & 4.2 \\
\hline \multirow[t]{3}{*}{ Glass } & EziG1 & Catechol-Fe ${ }^{3+}$ & 10 & $75-125$ & 0.14 & $99 \pm 2$ & 0.99 & 0.48 & 48 & 3.4 \\
\hline & EziG2 & Catechol-Fe ${ }^{3+}$ & 10 & $75-125$ & 0.14 & $98 \pm 2$ & 0.98 & 0.23 & 23 & 1.6 \\
\hline & EziG3 & Catechol-Fe ${ }^{3+}$ & 10 & $75-125$ & 0.13 & $99 \pm 1$ & 0.99 & 0.23 & 23 & 1.7 \\
\hline
\end{tabular}

For details of the immobilization parameters see Materials and Methods. $\psi$ : Immobilization yield. iA: theoretical immobilized activity. RA: recovered activity upon the immobilization. rRA: relative recovered activity. iSA: immobilized specific activity. The activity of BsADH was measured using 2s as substrate under the assay conditions described in methods. IDA: Imidodiacetic acid.

conditions: $10-100 \%$ of $\mathrm{B}$ over $30 \mathrm{~min}$. Retention time of derivatized 5-hydroxypentanal was $14.39 \mathrm{~min}$.

\section{RESULTS AND DISCUSSION}

\section{Enzyme Immobilization and Kinetic Characterization}

Initially, we studied the effect of different porous carriers and activation chemistries on the immobilization of a HisBsADH. For these studies we selected two types of commercially available materials with different types of functionalization; porous agarose microbeads (AG) functionalized with different types of ligands (imidodiacetates (IDA) and nitrotriacetates (NTA)) and densities of cobalt-chelates and porous glass particles (EziG) functionalized with $\mathrm{Fe}^{3+}$ catechol complexes (Table 1). According to previously reported protocols (Mateo et al., 2007a), we functionalized agarose porous microbeads with two different reactive groups; IDA-Co ${ }^{2+}$ and epoxides, giving rise to the carrier abbreviated as AG$\mathrm{Co}^{2+} / \mathrm{E}$ (Supplementary Figure 1). Among the different glassbased carriers, we tested three different ones presenting low (EziG1), medium (EziG3) and high (EziG2) hydrophobicity. When cell-free extracts of overexpressed His-BsADH in E. coli were incubated with the different carriers, we achieved immobilization yields higher than $95 \%$ with protein loads of at least $0.1 \mathrm{mg} \mathrm{x} \mathrm{g}^{-1}$ (Table 1). In contrast, the recovered enzymatic activity (RA) significantly varied depending on the hydrophobicity of the carrier but negligibly changed with metal type and density of the carrier. While His-BsADH recovered roughly $50 \%$ of its initial activity upon the immobilization on hydrophilic surfaces of all agarose-based carriers (LdAG-Co ${ }^{2+}, \mathrm{HdAG}-\mathrm{Co}^{2+}, \mathrm{tAG}-\mathrm{Co}^{2+}$ ), similar activity recoveries were only achieved when using the most hydrophilic glass-based carrier (EziG1). However, the more hydrophobic EziG2-3 resulted in lower recovered activities upon the immobilization process. When agarose-based carriers were functionalized with both cobalt and epoxide groups $\left(\mathrm{AG}-\mathrm{Co}^{2+} / \mathrm{E}\right)$, the enzyme recovered lower activity (22\%) than the carriers functionalized only with cobaltchelates. Hence, we suggest that $\mathrm{AG}-\mathrm{Co}^{2+} / \mathrm{E}$ promotes irreversible covalent bonds between the enzyme and the carrier that may distort the structure of the immobilized enzyme, negatively affecting its activity. To confirm the irreversibility of the immobilization on these heterofunctional carriers, we incubated all immobilized enzymes under denaturing conditions $\left(10 \%\right.$ SDS and $100^{\circ} \mathrm{C}$ for $5 \mathrm{~min}$ ), and the supernatants were analyzed by SDS-PAGE (Supplementary Figure 2). As expected, His-BsADH was released from all carriers but $\mathrm{AG}-\mathrm{Co}^{2+} / \mathrm{E}$ confirming that only those carriers functionalized with epoxide groups can irreversibly attach the enzyme. Similar results have been reported for other enzymes immobilized on other types of carriers functionalized with epoxide groups (Mateo et al., 2007a). Surprisingly, neither was the enzyme released from EziG1 although it was immobilized through reversible interactions between the His-tag and the $\mathrm{Fe}^{3+}$-catechol complexes (Supplementary Figure 2). Other strong interactions (i.e, electrostatic bonds) between the surface carrier and the enzymes may explain this unexpected behavior of His-BsADH bound to EziG1.

Furthermore, when we measured the specific activity of the immobilized enzymes, we observed higher values in the agarose-based carriers functionalized only with cobaltchelates. This finding points out that the combination of agarose matrix and cobalt-chelates enables a more selective and effective immobilization of His-tagged proteins as only His-BsADH was bound to the resins, recovering a higher specific activity. On the contrary, EziG1 may unspecifically bind other proteins besides His-BsADH, thus reducing the specific activity of the immobilized His-BsADH but recovering similar volumetric activities $\left(\mathrm{U} \times \mathrm{g}^{-1}\right)$ as with the AG carriers. As expected, the agarose matrix turns out to be the best system for the one-pot purification and immobilization of this His-tagged enzymes. In fact, this material is widely used to pack the chromatographic columns for protein purification (Cuatrecasas, 1970). 

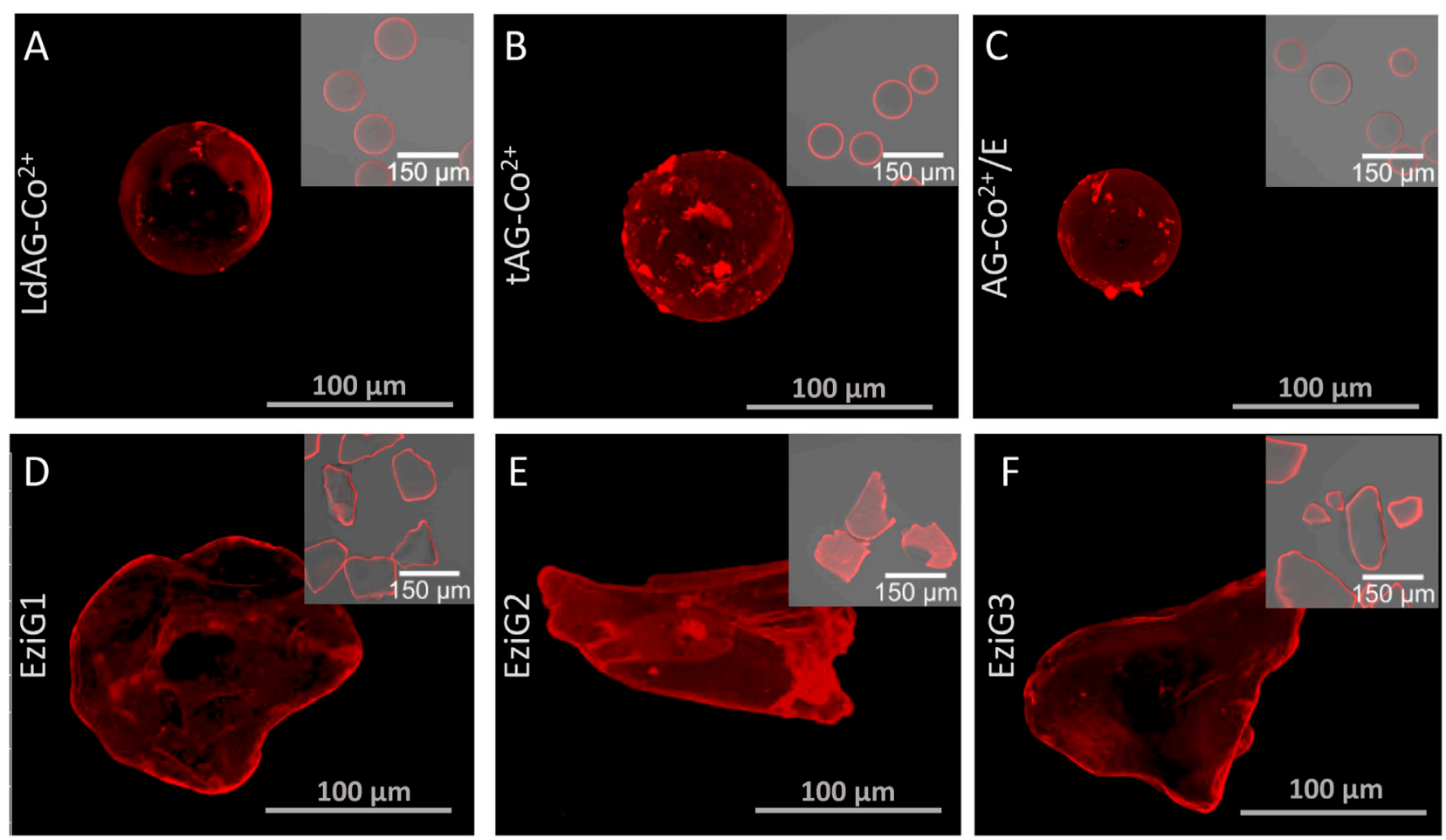

FIGURE 1 | Confocal fluorescence microscopic Z-stack images of immobilized His-BsADH labelled with Rhodamine (red channel) on LdAG-Co ${ }^{2+}$ (A), tAG-Co ${ }^{2+}$

(B), AG-Co ${ }^{2+} / E$ (C), EziG1 (D), EziG2 (E), EziG3 (F). Top right insets are lower magnification confocal fluorescence micrographs where red and bright field channels are overlaid.

\section{Spatial Distribution of His-BsADH Across the Porous Surface of Different Carriers}

Once the immobilization was characterized, we investigated the spatial organization of His-BsADH across the surface of the different porous carriers through confocal laser scanning microscopy (CLSM) imaging and through 3D image reconstruction (Figure 1). His-BsADH immobilized on agarose-based materials was similarly located at the most outer regions of the beads regardless the metal-complex ligands and the presence of epoxide groups (Figures 1A-C). A similar distribution pattern was found when EziG1 and EziG2 were used as carriers (Figures 1D,E). In all these carriers the enzyme was infiltrated only $2-3 \mu \mathrm{m}$ inside the particles (see Materials and Methods and supplementary information, Supplementary Figures 3 and 4). However, the more hydrophobic iron-complexed glass particles (EziG2) immobilized His-BsADH through a more uniform distribution, which meant that the proteins were infiltrated up to $35-42 \mu \mathrm{m}$ towards the inner surface of the particles. Interestingly, the $3 \mathrm{D}$ image reconstruction of the different immobilized biocatalysts revealed some different surface patterns for those samples with similar spatial distribution. While the enzymes immobilized on glass carriers regardless their spatial organization showed minor protein aggregates at their surface (inset
Figure1D-F), the agarose-based carriers promoted the protein aggregation at the surface of the particles. However, these different spatial organizations negligibly affected the functional parameters of the immobilized enzymes according to the Table $\mathbf{1}$.

\section{Thermal Inactivation}

All biocatalysts (including free enzyme) were incubated in a range of temperatures (from $20^{\circ} \mathrm{C}$ to $90^{\circ} \mathrm{C}$ ) to calculate their $\mathrm{T}_{50}$, temperature to which enzyme activity is reduced after $1 \mathrm{~h}$ of incubation (Supplementary Figure 5). Figure 2A shows that all agarose carriers raised up $5-10^{\circ} \mathrm{C}$ the $\mathrm{T}_{50}$ of His-BsADH compared to the free counterpart. Among glass carriers, only EziG1 was able to stabilize the enzyme, while its immobilization on EziG2 and EziG3 led to heterogeneous biocatalysts with lower $\mathrm{T}_{50}$ than the free enzyme. To further investigate the inactivation kinetics of the immobilized His-BsADH, we evaluated the thermal inactivation at $70^{\circ} \mathrm{C}$ for three selected carriers: $\mathrm{LdAG}-\mathrm{Co}^{2+}, \mathrm{AG}-\mathrm{Co}^{2+} / \mathrm{E}$ and EziG1. The inactivation courses (Figure 2B) show that the immobilization of His-BsADH on LdAG- $\mathrm{Co}^{2+}$, EziG1 and AG$\mathrm{Co}^{2+} / \mathrm{E}$ led to the enzyme stabilization, resulting in half-lives 3, 6, and 9 times higher than the free enzyme, respectively. Remarkably, EziG1 promotes a 2 times higher stabilization than LdAG- $\mathrm{Co}^{2+}$ but such carrier yielded a lower enzyme thermal stability than the AG$\mathrm{Co}^{2+} / \mathrm{E}$ carrier where His-BsADH is immobilized through a similar 

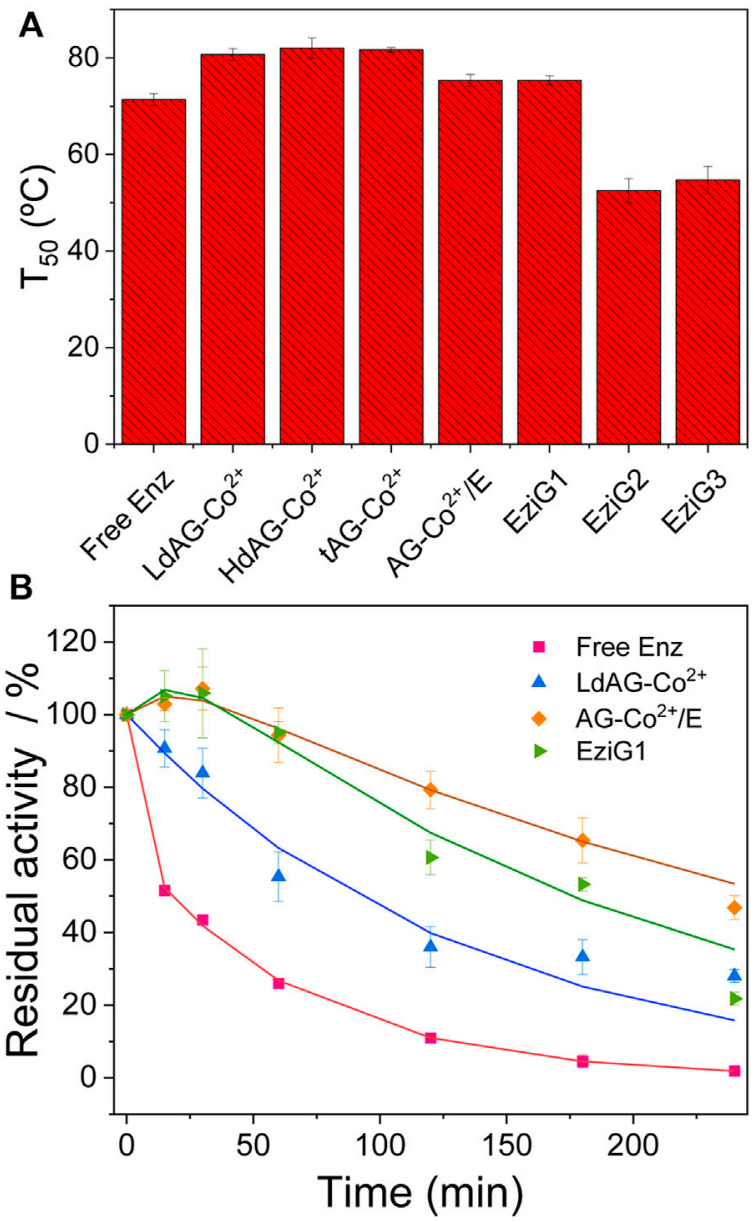

FIGURE 2 | Thermal inactivation of soluble and immobilized His-BsADH on different carriers. (A). $T_{50}$ means the temperature to which either the soluble or the immobilized enzyme lost $50 \%$ of its initial activity after $1 \mathrm{~h}$ incubation. (B) Thermal kinetic inactivation of different soluble and immobilized biocatalysts incubated at $70^{\circ} \mathrm{C}$ in sodium phosphate buffer $25 \mathrm{mM} \mathrm{pH}$ 7. The activity was measured with $2 \mathbf{s}$ as substrate under the assay conditions described in methods. Symbols represent the obtained experimental values, while the solid lines correspond to their fitting to 3parameters biexponential kinetic inactivation model (Aymard and Belarbi, 2000). Half-life time of the different samples: Free His-BsADH: $0.58 \mathrm{~h}$; HisBsADH immobilized on LdAG-Co2 ${ }^{+}: 1.51$ h, EziG1: 2.93 h, AG-Co2 ${ }^{+} / \mathrm{E}$ : $4.62 \mathrm{~h}$.

orientation but attached through irreversible bonds. These results are aligned with previous data reported for enzymes immobilized on heterofunctional carriers involving irreversible immobilization (Mateo et al., 2007b).

\section{Structural Analysis of Immobilized His-BsADH}

To understand the effect of the immobilization on the structure of His-BsADH, we performed a set of biophysical techniques to elucidate whether structural rearrangements occur during the immobilization and inactivation processes.
The emission fluorescence of aromatic residues reveals their microenvironment within the protein structure (Royer, 2006), thus structural changes upon immobilization and further thermal shock can be monitored through measuring the intrinsic fluorescence of proteins (Supplementary Figure 6). All immobilized enzymes shifted their $\lambda_{\max }$ towards lower wavelengths compared to the free enzyme, indicating that the aromatic residues of His-BsADH are less solvent exposed upon the immobilization process, most likely due to the interactions with the carrier surfaces (Figure 3A). When the biocatalysts were incubated at $80^{\circ} \mathrm{C}$ for $1 \mathrm{~h}$, the free enzyme exhibited a $15 \mathrm{~nm}$ red-shifted $\lambda_{\max }$ due to thermally induced unfolding, whereas that $\lambda_{\max }$ shift was minimized with all immobilized enzymes (Supplementary Table 1). Remarkably, there was no shift when the enzyme was immobilized on LdAG-Co ${ }^{2+}$. Additionally, we analyzed the maximum fluorescence intensity at the $\lambda_{\max }$ of each sample before and after thermal incubation. As shown in Figure 3B the immobilized enzyme reduced its maximum fluorescence intensity upon thermal shock. However, after the thermal incubation, all immobilized samples experienced a lower fluorescence decay than the free enzyme in agreement with the results obtained for the $\lambda_{\max }$ shift. These results point out a structural stabilization of His-BsADH upon the immobilization process, which is manifested in longer halflife times under high temperatures in comparison to the free enzyme.

Besides the structural rearrangements promoted by the immobilization, we also study the local motion of the immobilized enzymes when immobilized on this set of porous carriers. To that aim, we chemically labelled HisBsADH with FITC and then immobilized those fluorophores conjugated enzymes to perform anisotropy studies with both soluble and immobilized samples. Figure 3C reveals that the relative anisotropy of the immobilized enzymes is higher than the free one, indicating that all the herein tested immobilization protocols reduce the enzyme mobility. When comparing the normalized anisotropy values among the different immobilizates, we observe that the irreversible covalent immobilization on $\mathrm{AG}-\mathrm{Co}^{2+} / \mathrm{E}$ dramatically reduces the rotational tumbling of the anchored enzymes. Remarkably, there is a strong positive linear correlation $\left(\mathrm{R}^{2}=0.999\right)$ between the anisotropy values and the half-life time of the immobilized enzyme incubated at $80^{\circ} \mathrm{C}$. Therefore, the less mobile the immobilized enzyme is, the higher the stability. A similar trend was also found for the superfolded green fluorescent protein immobilized on agarose porous microbeads through different chemistries (Orrego et al., 2016). On the contrary, Figure 3D shows a negative correlation $\left(\mathrm{R}^{2}=0.932\right)$ between the specific activity of the immobilized enzymes and their normalized anisotropy values. Hence, our findings support that inverse correlations between activity and stability often found when comparing different immobilization protocols, is related with rotational mobility (anisotropy) of the immobilized enzyme. Single-molecule studies provided direct evidence that come to the same conclusion; the activity and the stability of immobilized 

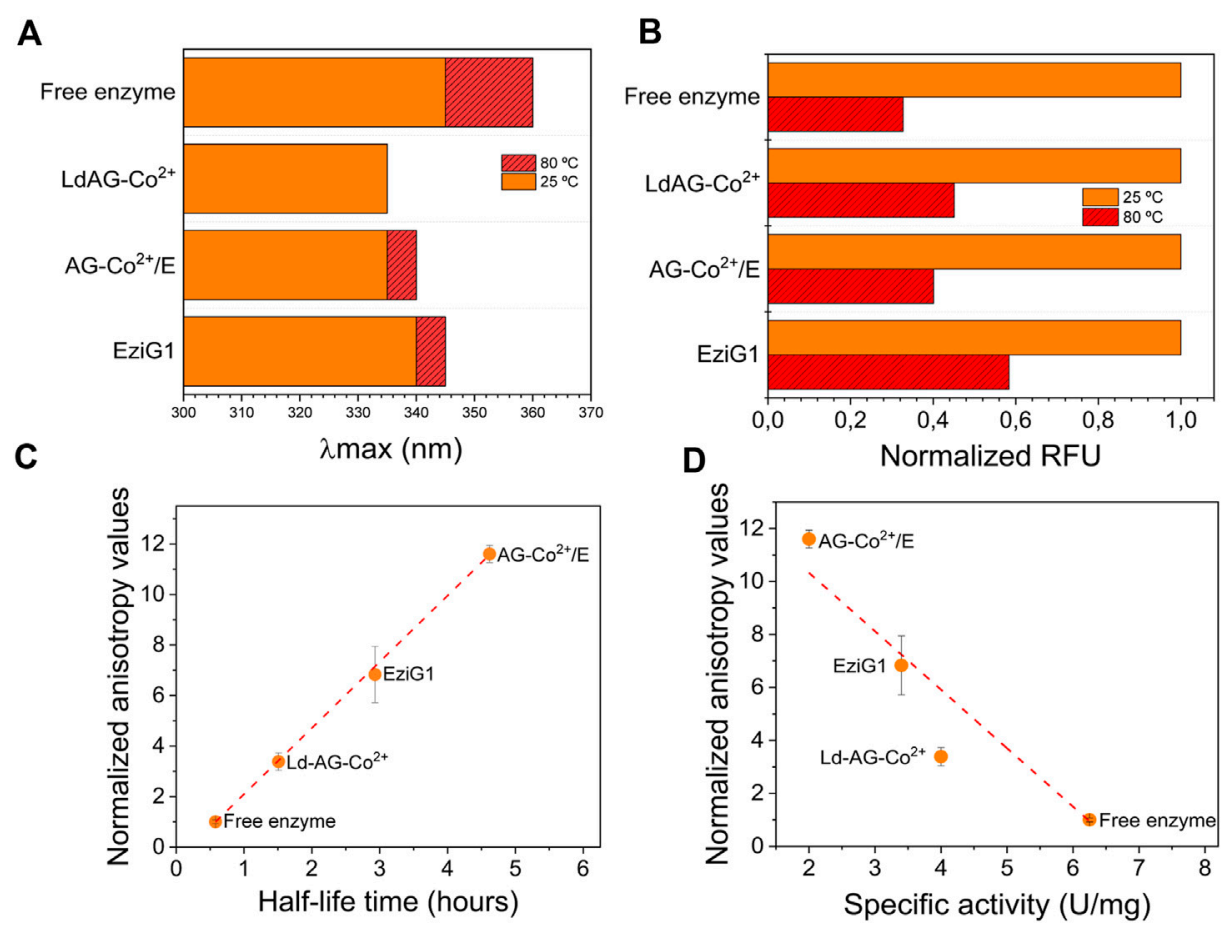

FIGURE 3 | Intrinsic fluorescence of free and immobilized His-BsADH. (A) $\lambda$ max of each biocatalyst before (solid orange bars) and after (red stripped bars) $1 \mathrm{~h}$ incubation at $80^{\circ} \mathrm{C}$. (B) Normalized RFU values for each biocatalyst before (orange bars) and after (red stripped bars) $1 \mathrm{~h}$ incubation at $80^{\circ} \mathrm{C}$. The RFUs of each sample before the thermal incubation were set as reference value of 1. (C) Normalized anisotropy as a function of the half-life time at $70^{\circ} \mathrm{C}$ (from Figure 4) of different His-BsADH immobilized on the different carriers. Fitting linear regression: $y=2.62 x-0.52 ; R^{2}=0.999$. (D) Normalized anisotropy as a function of the specific activity (from

Table 1) of different His-BsADH immobilized on the different carriers. Fitting linear regression: $y=-2.21+14.74 ; R^{2}=0.932$. Anisotropy values of each sample were normalized with the value of anisotropy of the free enzyme (Anisotropy of sample/Anisotropy of free enzyme).

enzymes must be balanced by controlling the extent of the enzyme attachment (Weltz et al., 2020).

\section{Operational Performance of the Different Immobilized Biocatalysts in Batch}

In order to select the optimal carrier to immobilize His-BsADH for its application in the regio-selective oxidation of $1, \omega$-diols, the three immobilized preparations previously characterized were incubated with a $\mathrm{NAD}^{+}$enzymatic recycling partner for the oxidation of 1,5-pentanediol to 5-hydroxy pentanal using catalytic amounts of the cofactor. First, we tested two putative recycling cofactor systems: one involving a His-tagged NADH oxidase from Lactobacillus pentosus (LpNOX) immobilized on LdAG- $\mathrm{Co}^{2+}$, and another one composed by NOX from Thermus thermophilus (TtNOX) and catalase from bovine liver (BlCAT) co-immobilized on agarose porous microbeads functionalized with aldehyde groups (AG-G). Using a diol:NAD ${ }^{+}$molar ratio 1 : 10, we incubated His-BsADH and the immobilized cofactor recycling systems in the same vessel to favor the in situ cofactor recycling. After $24 \mathrm{~h}$, the TtNOX/BlCAT system consumed close to $90 \%$ of the diol, nevertheless the recycling system based on immobilized LpNOX only reached a conversion of $50 \%$ (Supplementary Figure 7). The superior performance of TtNOX/
BlCAT system might be explained by the $40 \%$ higher catalytic efficiency of immobilized TtNOX compared to the immobilized LpNOX (Supplementary Table 2). Hence, we selected the coimmobilized TtNOX/BlCAT system to be coupled with the three immobilized preparations of His-BsADH to further test their operational stability. Figure $\mathbf{4 A}$ shows that all immobilized biocatalysts achieved $90 \%$ conversion of 1,5-pentanediol in the first cycle, majorly converting such diol into the 5-hydroxy pentanal (50-75\% yield) and its corresponding lactol (33-14\% yield) detected through HPLC and GC-FID (Supplementary Figures 8 and 9), respectively. It is described that these two molecules are in equilibrium under reaction conditions (Kara et al., 2013). Remarkably, the oxidation was practically regioselective towards only one of the hydroxy groups, as low yields $(<1.5 \%)$ of $\delta$-valerolactone and none of the other overoxidized products (dialdehyde, 5-hydroxy pentanoic) were detected upon the enzymatic reaction (Supplementary Figure 8 and Supplementary Table 3). However, His-BsADH immobilized on both $\mathrm{AG}-\mathrm{Co}^{2+} / \mathrm{E}$ and LdAG-Co ${ }^{2+}$ experienced a steady decrease in their productivity after the second batch cycle. In contrast, the enzyme immobilized on EziG1 kept a productivity close to $50 \%$ after 5 reaction cycles. This higher operational stability was manifested in a 2 and 1.2 higher accumulated enzyme TTN (defined as the moles of 1,5-pentanediol oxidized per mol of tetramer His-BsADH) after 5 

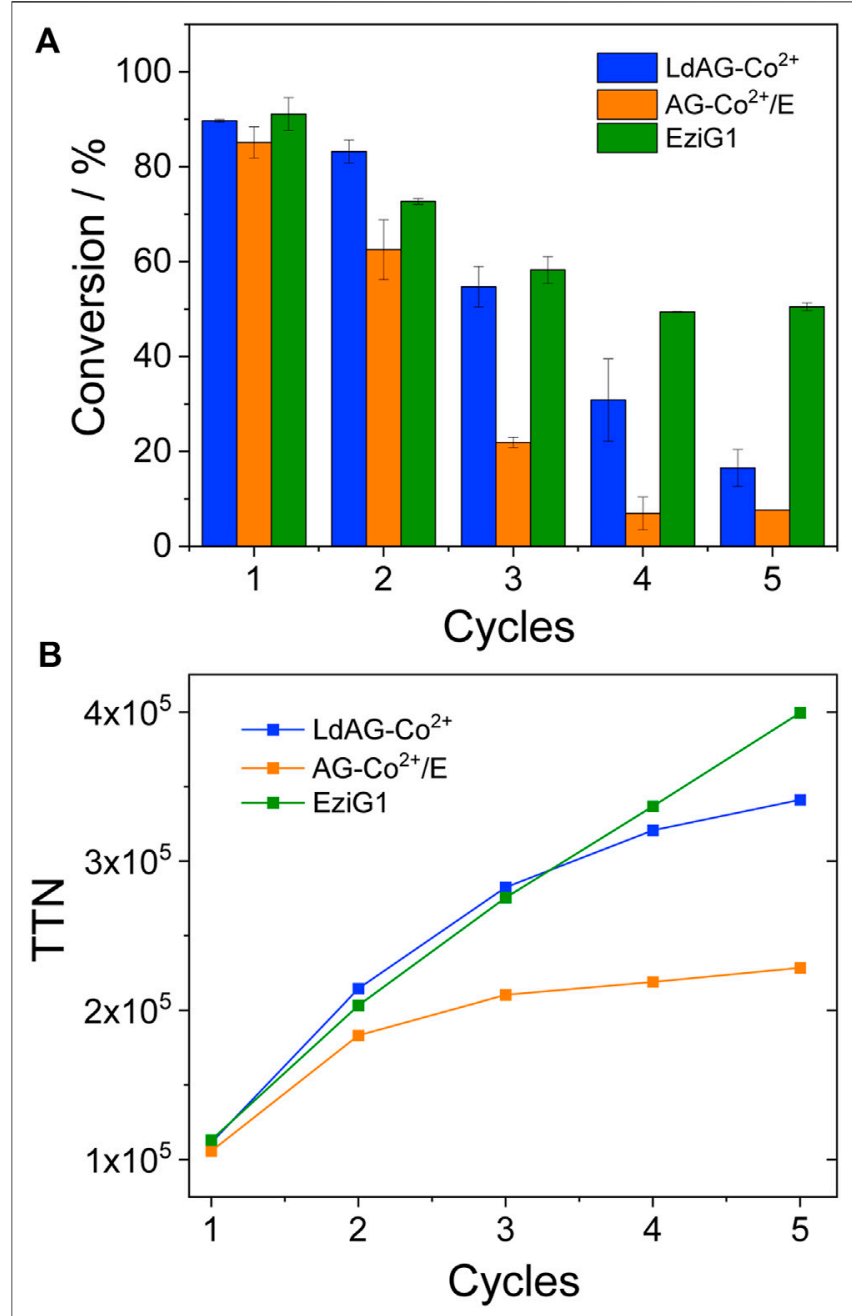

FIGURE 4 | Chromatographic conversion (A) and enzyme total turnover number (TTN) (B) during the oxidation of $2 \mathrm{~s}$ catalyzed by His-BsADH immobilized on different carriers: LdAG- $\mathrm{Co}^{2+}$ (blue), AG- $\mathrm{Co}^{2+} / \mathrm{E}$ (orange) and EziG1 (green) in consecutive batch reactors. Reactions were carried out at $20 \mathrm{mM}$ of $2 \mathrm{~s}$ and $1 \mathrm{mM}$ of soluble $\mathrm{NAD}^{+}$in $50 \mathrm{mM}$ Tris- $\mathrm{HCl}$ buffered solution $\mathrm{pH} 8$ at $30^{\circ} \mathrm{C}$. TTN was calculated as the sum of moles of $2 \mathrm{~s}$ oxidized after each cycle by one mole of immobilized enzyme.

reaction cycles and in comparison, with the enzyme immobilized on $\mathrm{AG}-\mathrm{Co}^{2+} / \mathrm{E}$ and LdAG-Co ${ }^{2+}$ respectively (Figure 4B). When we studied the leaching of His-BsADH from the carriers, we observed that the enzyme remains in the resins $\mathrm{AG}-\mathrm{Co}^{2+} / \mathrm{E}$ and EziG1 upon their incubation under denaturing conditions for SDS-PAGE analysis (Supplementary Figure 2), entailing that $100 \%$ of the protein remained bound to $\mathrm{AG}-\mathrm{Co}^{2+} / \mathrm{E}$ and EziG1 after 5 batch operational cycles. On the contrary, the operational conditions were sufficient to cause the quantitative lixiviation of the enzyme from the resin LdAG-Co ${ }^{2+}$ (Supplementary Figure 10). In the light of these data, we suggest that the operational inactivation of His-BsADH immobilized on LdAG-Co ${ }^{2+}$ is caused by the enzyme lixiviation. In contrast the enzymes immobilized on $\mathrm{AG}-\mathrm{Co}^{2+} / \mathrm{E}$ on EziG1 seems to be operationally inactivated through structural distortion, rather than through enzyme leaching after each reaction cycle. Similar negligible enzyme leaching was observed for other His-tagged enzymes immobilized as protein-inorganic hybrids (Das et al., 2021).

Remarkably, the accumulated TTN after re-using the immobilized enzyme in EziG1 reached values as high as $4 \times$ $10^{5}$ one of the highest values ever reported for an immobilized alcohol dehydrogenase (Bolivar and López-Gallego, 2020). In comparison to the TTN estimated for upscaled selective oxidation of lactols using a soluble $\mathrm{ADH} / \mathrm{NOX}$ system (Aalbers et al., 2020), the herein reported heterogeneous biocatalyst presents one order of magnitude higher TTN for the oxidation of $1, \omega$-diols to their corresponding lactols. It is worth mentioning that the most robust and efficient heterogeneous biocatalysts under operational conditions (His-BsADH immobilized on EziG1) was not the most thermostable one. On the contrary the most thermostable heterogenous biocatalyst (His-BsADH immobilized on $\mathrm{AG}-\mathrm{Co}^{2+} / \mathrm{E}$ ) was the least productive and stable operationally. This divergence between thermal and operational stability might rely on the different inactivation mechanisms triggered during either the thermal shock (in absence of substrates) or the batch oxidation process (in presence of substrate and cofactor). A similar divergence has been reported for a pyruvate aldolase thermostabilized through directed evolution (Bosch et al., 2021).

The excellent immobilization parameters, the structural integrity, the high thermal and operational stability and the high accumulated TTN of His-BsADH immobilized on EziG1 led us to select this heterogeneous biocatalyst for its application in the oxidation of a battery of different diols, employing the co-immobilized TtNOX/ BlCAT $\mathrm{NAD}^{+}$recycling system. To that aim, we evaluated the substrate conversion, the enzyme productivity, and the volumetric productivity of this heterogeneous multi-enzyme system towards the oxidation of five different 1, $\omega$-diols (Table 2, Supplementary Table 2). As expected, the system achieved the oxidation of linear aliphatic 1, $\omega$-diols, but failed to convert branched and etherified $1, \omega$-diols. The immobilized His-BsADH oxidizes the 5 and 6 carbon 1, $\omega$-diols more rapidly than the shorter ones.

\section{CONCLUSION}

In this study, we have screened a battery of porous carriers and immobilization chemistries to enhance the robustness of a His-tagged variant of $\mathrm{BsADH}$. Through characterizing the activity and structural changes undergone by the enzyme upon the immobilization, we reveled the impact of the different immobilization protocols on the enzyme properties. While the irreversible attachment of His-BsADH to agarose microbeads functionalized with cobalt-complexes and epoxides (AG-Co ${ }^{2+} / \mathrm{E}$ ) enhances the enzyme thermal stability, such immobilization protocol yields a less operationally stable biocatalyst. On the contrary when the enzyme was immobilized on glass-based carriers functionalized with iron-complexes (EziG1), its thermal stability was lower, but the heterogeneous biocatalyst was surprisingly more stable under operation conditions. This latter heterogeneous biocatalyst was successfully mixed with a $\mathrm{NADH}$ oxidase and a catalase co-immobilized on a different porous carrier to selectively oxidize $1, \omega$-diols, integrating an in situ $\mathrm{NAD}^{+}$ 
TABLE 2 | Biocatalytic oxidation of diols catalyzed by immobilized His-BsADH on EziG1 coupled with an immobilized enzymatic cofactor regeneration system (TtNOX and BICAT co-immobilized on AG-G).

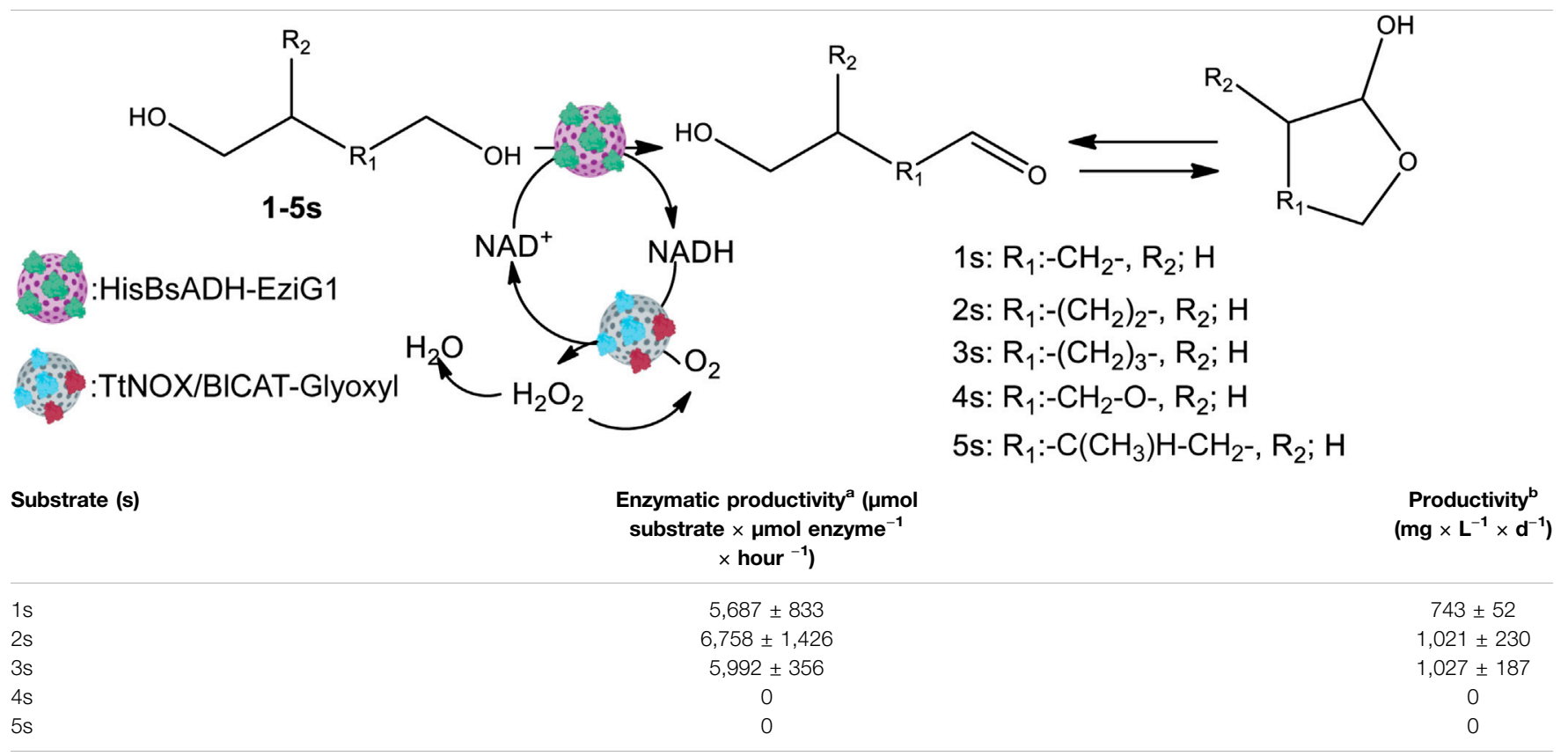

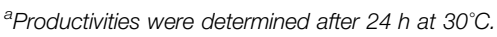

${ }^{b} 250$ r.p.m. shaking.

All reaction mixtures consisted in substrate $20 \mathrm{mM}, \mathrm{NAD}^{+} 1 \mathrm{mM}$ in Tris- $\mathrm{HCl} 50 \mathrm{mM}$ at $\mathrm{pH} 8$.

recycling system in batch. This immobilized multi-enzyme systems could be recycled up to 5 cycles, retaining more than $50 \%$ of its initial conversion. Finally, we tested the substrate scope of His-BsADH immobilized on EziG1, proving the versatility of this enzyme towards the oxidation of linear aliphatic 1, $\omega$-diols. This work illustrates how the optimization of a heterogeneous biocatalyst must be accompanied by its functional and structural characterization. Remarkably, the determination of the anisotropy exhibited by the fluorophore-labelled and immobilized enzymes is revealed as a very informative parameter that unveils an activity/stability trade-off that depends on the structural dynamics of the immobilized enzyme. The optimization and characterization pathway herein reported will surely help to rationalize new immobilization protocols to fabricate more active and robust immobilized biocatalysts.

\section{DATA AVAILABILITY STATEMENT}

The original contributions presented in the study are included in the article/Supplementary Material, further inquiries can be directed to the corresponding author.

\section{AUTHOR CONTRIBUTIONS}

FL-G conceived the study, FL-G and JS-A prepared and wrote the manuscript. JS-A, SV-L and ED performed the experiments and the characterization studies. FL-G and AC supervised the experiments. All authors discussed the results and reviewed the manuscript.

\section{FUNDING}

This work has been funded by Era-CoBiotech (Project ID: 61 HOMBIOCAT) and Spanish State Research Agency (AIE) (RTI 2018-094398-B-I00, PCI 2018-092984, PID 2019111649RB-I00). This work was performed under the Maria de Maeztu Units of Excellence Program from the Spanish State Research Agency-Grant no. MDM-2017-0720 (CIC biomaGUNE).

\section{ACKNOWLEDGMENTS}

We thank K. E. Cassimjee (EnginZyme AB) for kindly providing us a set of EziG carriers.

\section{SUPPLEMENTARY MATERIAL}

The Supplementary Material for this article can be found online at: https:/www.frontiersin.org/articles/10.3389/fctls.2021.715075/ full\#supplementary-material 


\section{REFERENCES}

Aymard, C., and Belarbi, A. (2000). Kinetics of thermal Deactivation of Enzymes: a Simple Three Parameters Phenomenological Model Can Describe the Decay of Enzyme Activity, Irrespectively of the Mechanism. Enzyme Microb. Tech. 27, 612-618. doi:10.1016/s0141-0229(00)00258-1

Aalbers, F. S., Furst, M. J., Rovida, S., Trajkovic, M., Castellanos, J. R. G., Bartsch, S., et al. (2020). Approaching boiling point stability of an alcohol dehydrogenase through computationally-guided enzyme engineering. Elife 9, e54639. doi:10.7554/eLife.54639.sa2

Basso, A., and Serban, S. (2019). Industrial Applications of Immobilized EnzymesA Review. Mol. Catal. 479, 110607. doi:10.1016/j.mcat.2019.110607

Bolivar, J. M., Wilson, L., Ferrarotti, S. A., Fernandez-Lafuente, R., Guisan, J. M., and Mateo, C. (2006). Stabilization of a Formate Dehydrogenase by Covalent Immobilization on Highly Activated Glyoxyl-Agarose Supports. Biomacromolecules 7, 669-673. doi:10.1021/bm050947z

Bolivar, J. M., and López-Gallego, F. (2020). Characterization and evaluation of immobilized enzymes for applications in flow reactors. Curr. Opin. Green Sustain. Chem. 25, 100349. doi:10.1016/j.cogsc.2020.04.010

Bosch, S., Sanchez-Freire, E., Del Pozo, M. L., ČEsnik, M., Quesada, J., Mate, D. M., et al. (2021). Thermostability Engineering of a Class II Pyruvate Aldolase from Escherichia coli by In Vivo Folding Interference. ACS Sustain. Chem. Eng. 9, 5430. doi:10.1021/acssuschemeng.1 100699

Bradford, N. (1976). A Rapid and Sensitive Method for the Quantitation Microgram Quantities of a Protein Isolated from Red Cell Membranes. Anal. Biochem. 72, e254. doi:10.1016/0003-2697(76)90527-3

Cantone, S., Ferrario, V., Corici, L., Ebert, C., Fattor, D., Spizzo, P., et al. (2013). Efficient Immobilisation of Industrial Biocatalysts: Criteria and Constraints for the Selection of Organic Polymeric Carriers and Immobilisation Methods. Chem. Soc. Rev. 42, 6262-6276. doi:10.1039/ c3cs35464d

Chung, H., Yang, J. E., Ha, J. Y., Chae, T. U., Shin, J. H., Gustavsson, M., et al. (2015). Bio-based Production of Monomers and Polymers by Metabolically Engineered Microorganisms. Curr. Opin. Biotechnol. 36, 73-84. doi:10.1016/ j.copbio.2015.07.003

Contente, M. L., Farris, S., Tamborini, L., Molinari, F., and Paradisi, F. (2019). Flow-based Enzymatic Synthesis of Melatonin and Other High Value Tryptamine Derivatives: A Five-Minute Intensified Process. Green. Chem. 21, 3263-3266. doi:10.1039/c9gc01374a

Cuatrecasas, P. (1970). Agarose Derivatives for Purification of Protein by Affinity Chromatography. Nature 228, 1327-1328. doi:10.1038/2281327a0

Das, S., Ashok, Z., Bian, N., Dewangan, M. H., Wai, Y., Du, A., et al. (2018). Silica-Ceria sandwiched $\mathrm{Ni}$ core-shell catalyst for low temperature dry reforming of biogas: Coke resistance and mechanistic insights. Appl. Catal, B: Environ. 230, 220-236. doi:10.1016/j.apcatb.2018.02.041

Dickinson, F. M., and Monger, G. P. (1973). A study of the kinetics and mechanism of yeast alcohol dehydrogenase with a variety of substrates. Biochem J. 131 (2), 261-270. doi:10.1042/bj1310261

Fixler, D., Namer, Y., Yishay, Y., and Deutsch, M. (2006). Influence of Fluorescence Anisotropy on Fluorescence Intensity and Lifetime Measurement: Theory, Simulations and Experiments. IEEE Trans. Biomed. Eng. 53, 1141-1152. doi:10.1109/tbme.2006.873539

Garcia-Galan, C., Berenguer-Murcia, Á., Fernandez-Lafuente, R., and Rodrigues, R. C. (2011). Potential of Different Enzyme Immobilization Strategies to Improve Enzyme Performance. Adv. Synth. Catal. 353, 2885-2904. doi:10.1002/adsc.201100534

Guisán, J. (1988). Aldehyde-agarose Gels as Activated Supports for Immobilization-Stabilization of Enzymes. Enzyme Microb. Technol. 10, 375-382. doi:10.1016/0141-0229(88)90018-X

Hernandez, K., Bujons, J., Joglar, J., Charnock, S. J., Domínguez de María, P., Fessner, W. D., et al. (2017). Combining Aldolases and Transaminases for the Synthesis of 2-Amino-4-Hydroxybutanoic Acid. ACS Catal. 7, 1707-1711. doi:10.1021/acscatal.6b03181

Holmes, K. L., and Lantz, L. M. (2001). Chapter 9 Protein Labeling with Fluorescent Probes. Methods Cel. Biol. 63, 185-204. doi:10.1016/s0091$679 \mathrm{x}(01) 63013-9$
Huang, L., Bittner, J. P., Domínguez de María, P., Jakobtorweihen, S., and Kara, S (2020). Modeling Alcohol Dehydrogenase Catalysis in Deep Eutectic Solvent/ water Mixtures. ChemBioChem 21, 811-817. doi:10.1002/cbic.201900624

Kara, S., Spickermann, D., Schrittwieser, J. H., Weckbecker, A., Leggewie, C., Arends, I. W. C. E., et al. (2013). Access to Lactone Building Blocks via Horse Liver Alcohol Dehydrogenase-Catalyzed Oxidative Lactonization. ACS Catal. 3 , 2436-2439. doi:10.1021/cs400535c

Kirmair, L., Seiler, D. L., and Skerra, A. (2015). Stability Engineering of the Geobacillus Stearothermophilus Alcohol Dehydrogenase and Application for the Synthesis of a Polyamide 12 Precursor. Appl. Microbiol. Biotechnol. 99, 10501-10513. doi:10.1007/s00253-015-6930-5

Köckritz, A., and Martin, A. (2011). Synthesis of Azelaic Acid from Vegetable OilBased Feedstocks. Eur. J. Lipid Sci. Technol. 113, 83-91. doi:10.1002/ ejlt.201000117

Kornhauser, A., Coelho, S. G., and Hearing, V. J. (2010). Applications of Hydroxy Acids: Classification, Mechanisms, and Photoactivity. Ccid 3, 135-142. doi: $10.2147 /$ ccid.s9042

Liu, J., Liang, J., Xue, J., and Liang, K. (2021). Metal-Organic Frameworks as a Versatile Materials Platform for Unlocking New Potentials in Biocatalysis. Small, e2100300. doi:10.1002/smll.202100300

Liu, N., Nie, D., Tan, Y., Zhao, Z., Liao, Y., Wang, H., et al. (2017). An Ultrasensitive Amperometric Immunosensor for Zearalenones Based on Oriented Antibody Immobilization on a Glassy Carbon Electrode Modified with MWCNTs and AuPt Nanoparticles. Microchim. Acta 184, 147-153. doi:10.1007/s00604-016-1996-z

López-Gallego, F., and Yate, L. (2015). Selective Biomineralization of Co3(PO4)2Sponges Triggered by His-Tagged Proteins: Efficient Heterogeneous Biocatalysts for Redox Processes. Chem. Commun. 51, 8753-8756. doi: $10.1039 / \mathrm{c} 5 \mathrm{cc} 00318 \mathrm{k}$

Marchesi, A., Parmeggiani, F., Louçano, J., Mattey, A. P., Huang, K., Gupta, T., et al. (2020). Enzymatic Building-Block Synthesis for Solid-Phase Automated Glycan Assembly. Angew. Chem. Int. Ed. 59, 22456-22459. doi:10.1002/anie.202008067

Mateo, C., Grazu, V., Palomo, J. M., Lopez-Gallego, F., Fernandez-Lafuente, R., and Guisan, J. M. (2007a). Immobilization of Enzymes on Heterofunctional Epoxy Supports. Nat. Protoc. 2, 1022-1033. doi:10.1038/nprot.2007.133

Mateo, C., Grazú, V., Pessela, B. C. C., Montes, T., Palomo, J. M., Torres, R., et al. (2007b). Advances in the Design of New Epoxy Supports for Enzyme Immobilization-Stabilization. Biochem. Soc. Trans. 35, 1593-1601. doi:10.1042/bst0351593

Mateo, C., Pessela, B. C. C., Grazu, V., Torres, R., López-Gallego, F., Guisan, J. M., et al. (2006). "One-Step Purification, Immobilization, and Stabilization of PolyHistidine-Tagged Enzymes Using Metal Chelate-Epoxy Supports," in Immobilization Of Enzymes And Cells. Editor J. M. Guisan (Totowa, NJ: Humana Press), 117-128. doi:10.1007/978-1-59745-053-9 11

Nowak, C., Beer, B. C., Pick, A., Roth, T., Lommes, P., and Sieber, V. (2015). A Water-Forming NADH Oxidase from Lactobacillus Pentosus Suitable for the Regeneration of Synthetic Biomimetic Cofactors. Front. Microbiol. 6, 957. doi:10.3389/fmicb.2015.00957

Orrego, A. H., García, C., Mancheño, J. M., Guisán, J. M., Lillo, M. P., and LópezGallego, F. (2016). Two-Photon Fluorescence Anisotropy Imaging to Elucidate the Dynamics and the Stability of Immobilized Proteins. J. Phys. Chem. B 120, 485-491. doi:10.1021/acs.jpcb.5b12385

Padrosa, D. R., Benítez-Mateos, A. I., Calvey, L., and Paradisi, F. (2020). Cell-free Biocatalytic Syntheses of L-Pipecolic Acid: a Dual Strategy Approach and Process Intensification in Flow. Green. Chem. 22, 5310-5316.

Patel, S. K. S., Otari, S. V., Chan Kang, Y., and Lee, J.-K. (2017). Protein-inorganic Hybrid System for Efficient His-Tagged Enzymes Immobilization and its Application in L-Xylulose Production. RSC Adv. 7, 3488-3494. doi:10.1039/ c6ra24404a

Pham, N. H., Hollmann, F., Kracher, D., Preims, M., Haltrich, D., and Ludwig, R. (2015). Engineering an Enzymatic Regeneration System for $\mathrm{NAD}(\mathrm{P}) \mathrm{H}$ Oxidation. J. Mol. Catal. B: Enzymatic 120, 38-46. doi:10.1016/ j.molcatb.2015.06.011

Puetz, H., Puchlová, E., Vranková, K., and Hollmann, F. (2020). Biocatalytic Oxidation of Alcohols. Catalysts 10, 952. doi:10.3390/catal10090952

Rocha-Martin, J., Acosta, A., Guisan, J. M., and López-Gallego, F. (2015). Immobilizing Systems Biocatalysis for the Selective Oxidation of Glycerol 
Coupled to In Situ Cofactor Recycling and Hydrogen Peroxide Elimination. ChemCatChem 7, 1939-1947. doi:10.1002/cctc.201500210

Rocha-Martín, J., Vega, D., Bolivar, J. M., Godoy, C. A., Hidalgo, A., Berenguer, J., et al. (2011). New Biotechnological Perspectives of a NADH Oxidase Variant from Thermus Thermophilus HB27 as NAD+-recycling Enzyme. BMC Biotechnol. 11, 101. doi:10.1186/1472-6750-11-101

Royer, C. A. (2006). Probing Protein Folding and Conformational Transitions with Fluorescence. Chem. Rev. 106, 1769-1784. doi:10.1021/cr0404390

Schindelin, J., Arganda-Carreras, I., Frise, E., Kaynig, V., Longair, M., Pietzsch, T., et al. (2012). Fiji: an Open-Source Platform for Biological-Image Analysis. Nat. Methods 9, 676-682. doi:10.1038/nmeth.2019

Schrittwieser, J. H., Sattler, J., Resch, V., Mutti, F. G., and Kroutil, W. (2011). Recent Biocatalytic Oxidation-Reduction Cascades. Curr. Opin. Chem. Biol. 15, 249-256. doi:10.1016/j.cbpa.2010.11.010

Sheldon, R. A., Basso, A., and Brady, D. (2021). New Frontiers in Enzyme Immobilisation: Robust Biocatalysts for a Circular Bio-Based Economy. Chem. Soc. Rev. 50, 5850-5862. doi:10.30573/ks-2021-dp04

Thompson, M. P., Derrington, S. R., Heath, R. S., Porter, J. L., Mangas-Sanchez, J., Devine, P. N., et al. (2019). A Generic Platform for the Immobilisation of Engineered Biocatalysts. Tetrahedron 75, 327-334. doi:10.1016/j.tet.2018.12.004

Tojo, G., and Fernandez, M. I. (2006). Oxidation of Alcohols to Aldehydes and Ketones: a Guide to Current Common Practice. Springer Science \& Business Media.

Velasco-Lozano, S., Santiago-Arcos, J., Mayoral, J. A., and López-Gallego, F. (2020). Co-immobilization and Colocalization of Multi-Enzyme Systems for the Cell-free Biosynthesis of Aminoalcohols. ChemCatChem 12, 3030-3041. doi:10.1002/cctc.201902404

Weltz, J. S., Kienle, D. F., Schwartz, D. K., and Kaar, J. L. (2020). Reduced enzyme dynamics upon multipoint covalent immobilization leads to stability-activity trade-off. J. Am. Chem. Soc. 142, 3463-3471. doi:10.1021/jacs.9b11707

Wu, S., Snajdrova, R., Moore, J. C., Baldenius, K., and Bornscheuer, U. T. (2021). Biocatalysis: Enzymatic Synthesis for Industrial Applications. Angew. Chem. Int. Ed. 60, 88-119. doi:10.1002/anie.202006648

Zhang, M., Zhang, Y., Yang, C., Ma, C., and Tang, J. (2021). Enzyme-inorganic Hybrid Nanoflowers: Classification, Synthesis, Functionalization and Potential Applications. Chem. Eng. J. 415, 129075. doi:10.1016/j.cej.2021.129075

Conflict of Interest: The authors declare that the research was conducted in the absence of any commercial or financial relationships that could be construed as a potential conflict of interest.

Copyright $\odot 2021$ Santiago-Arcos, Velasco-Lozano, Diamanti, Cortajarena and López-Gallego. This is an open-access article distributed under the terms of the Creative Commons Attribution License (CC BY). The use, distribution or reproduction in other forums is permitted, provided the original author(s) and the copyright owner(s) are credited and that the original publication in this journal is cited, in accordance with accepted academic practice. No use, distribution or reproduction is permitted which does not comply with these terms. 